\title{
ON THE DISTRIBUTION AND FOOD PREFERENCES OF ARION SUBFUSCUS (DRAPARNAUD, 1805)
}

\author{
JAN KOZŁOWSKI
}

Institute of Plant Protection, National Research Institute, Władysława Węgorka 20, 60-318 Poznań, Poland (e-mail: janjkozlowski@o2.pl)

ABSTRACT: In recent years Arion subfuscus (Drap.) is increasingly often observed in agricultural crops. Its abundance and effect on winter oilseed rape crops were studied. Its abundance was found to be much lower than that of Deroceras reticulatum (O. F. Müll.). Preferences of A. subfuscus to oilseed rape and 19 other herbaceous plants were determined based on multiple choice tests in the laboratory. Indices of acceptance (A.I.), palatability (P.I.) and consumption (C.I.) were calculated for the studied plant species; accepted and not accepted plant species were identified. A. subfuscus was found to prefer seedlings of Brassica napus, while Chelidonium maius, Euphorbia helioscopia and Plantago lanceolata were not accepted.

KEY WORDS: Arion subfuscus, abundance, oilseed rape seedlings, herbaceous plants, acceptance of plants

\section{INTRODUCTION}

Pulmonate slugs are seroius pests of plants cultivated in Poland and in other parts of western and central Europe (GLEN et al. 1993, MESCH 1996, FRANK 1998, MOENS \& GLEN 2002, PORT \& ESTER 2002, KOZŁOWSKI 2003). The most important pest species include Deroceras reticulatum (O. F. Müller, 1774), and slugs occurring in some regions of the country: Arion lusitanicus Mabille, 1868, A. rufus (Linnaeus, 1758) and A. distinctus Mabille, 1868. Besides, much damage to plants can be done by other members of the families Agriolimacidae, Arionidae and Limacidae. Arion subfuscus (Draparnaud, 1805) has recently become a significant pest; it occurs in gardens and fields (SIONEK \& KOZŁOWSKI 1999, KOZŁOWSKI 2003).

Arion subfuscus is a complex of species including three forms of different external appearance and distribution (RIEDEL \& WIKTOR 1974, RIEDEL 1988, WIKTOR 1973, 2004). Based on specimens collected in Spain it has been shown that A. subfuscus is a complex of five forms (GARRIDO et al. 1995). Probably only one of them is present in Poland; pending revision it has been called Arion (Mesarion) "subfuscus" by WIKTOR (2004).

The slug occurs in almost the whole of Europe, from Portugal and Iceland to the Urals; in Poland it is common (RIEDEL 1988, WIKTOR 2004). It lives in lowland and montane forests, shrubs, on meadows, montane glades and sometimes even in peat bogs. Recently it has been observed to occur synanthropically in such habitats as ruins, parks, cemeteries, gardens and margins of cultivated fields.

A. subfuscus is known as a fungivore (FRÖMMING 1954, CHICHESTER \& GETZ 1969, 1973). It consumes fruiting bodies of edible and poisonous mushrooms. FRÖMMING (1954) regards it as an omnivore which eats mushrooms only in the absence of other food. Information on its possible significance as pest is scanty. The slug is known to damage some vegetables, cereals, oilseed rape, soya and sunflower (GLEN et al. 1992, HAMMOND \& BYERS 2002, HOMMAY 2002, GLEN \& MOENS 2002).

During field studies on other slug species $A$. subfuscus was observed to feed readily on dicotyledon weeds growing near winter oilseed rape fields and other plantations (own, unpublished results). The aim of this study was to assess the occurrence of $A$. subfuscus in winter oilseed rape plantations, to estimate the degree of acceptance of oilseed rape seedlings and various other plants by the slug and their palatability. 


\section{MATERIAL AND METHODS}

\section{FIELD OBSERVATIONS}

Field observations were conducted in the late summer of 2006 in two plantations of oilseed rape of Lisek variety. One plantation was located near Kłodzko, the other in Pisarzowice near Bielsko-Biała. After germination of oilseed rape 15 baited traps were placed in each plantation. Each trap was a mat of $50 \times 50 \mathrm{~cm}$ made of felt, with upper side covered with aluminium foil and underside - with black plastic foil (KOZŁOWSKI 2008). The soil under the mats was abundantly moistened, and baits in the form of wheat bran and cabbage leaves were placed on it. After a few days, at the stage of two leaves of the winter oilseed rape (BBCH-12), slugs of different species were counted. Besides, in 12 randomly selected places in each plantation damage to ten plants was estimated visually according to a five-degree scale (KOZŁOWSKI \& KOZŁOWSKA 2004).

\section{IDENTIFICATION AND LABORATORY CULTURE OF A. SUBFUSCUS}

The slugs used in the studies came from a population from a copse $5 \mathrm{~km}$ from Kłodzko. Prior to the experiment about a dozen individuals were identified based on the structure of their genitalia and other diagnostic characters, and comparison with available descriptions (RIEDEL \& WIKTOR 1974, WIKTOR 2004). Then slug culture was established in the laboratory of the Plant Protection Institute in Poznań, with a few dozen individuals of A. subfuscus. They were placed in plastic, ventilated containers $(50 \times 35 \times 40 \mathrm{~cm})$ filled with a $5 \mathrm{~cm}$ layer of clayey-humic soil. Three times a week food was exchanged in the containers (pieces of potato tubers, wheat bran, powdered milk and calcium carbonate). The containers were kept in a climatic chamber at daytime temperature of $19^{\circ} \mathrm{C}$, night temperature $16^{\circ} \mathrm{C}, \mathrm{RH} 93 \% \pm 2 \%$ and day length $14 \mathrm{~h}$.

\section{CHOICE TEST}

Multiple choice tests were run in the above temperature, humidity and lighting conditions, in order to determine food preferences of $A$. subfuscus to oilseed rape and 19 species of herbaceous plants. The tests were done in ventilated, closed plastic containers $(80 \times 40 \times 20 \mathrm{~cm})$, filled with soil up to $1 / 3$ and divided into 40 micro-fields. Ten seeds of each studied plant species were sown in each container, five on each of two micro-fields. Because of different germination and development time of various plants the time of planting was adjusted in order to obtain an equalized plant material. When the plants reached the stage of 2-3 leaves and the height of 5-8 cm, 10 starved $(48 \mathrm{~h})$ slugs of the mean body mass of $0.9 \mathrm{~g}$ were placed in the middle of each container under a plastic shelter. Every few days the proportion of consumed plants was assessed according to a five-degree scale $(0 \%$ - no damage, $25 \%, 50 \%, 75 \%$ and $100 \%$ consumed plant area). Damage to 30 plants of each of the 20 species was assessed.

The nested block design included three blocks. Two sub-blocks were nested in block, each with 20 micro-fields. Six replicates were used for the 19 test objects (herbaceous plants) and the model object (oilseed rape). Based on observations of five plants from the micro-field, the mean percentage of consumed plant area after 1, 3, 10 and 20 days was calculated for each micro-field. The results obtained on consecutive dates of observations were subject to variance analysis and Tukey multiple comparisons at the significance level of $\alpha=0.05$. The rate of damage was determined; acceptability (A.I.), palatability (P.I.) and consumption (C.I.) indices were calculated for each plant species (KOZŁOWSKA \& KOZŁOWSKI 2002). The index values were calculated for the third day of slug feeding, according to compatibility index (KOZŁOWSKA \& KOZŁOWSKI 2004).

The values of A.I., P.I. and C.I. convey different information. Acceptability is the intensity of slug feeding on plants of the species concerned in relation to the mean intensity of feeding on the remaining species. Palatability is the intensity of slug feeding on the species concerned in relation to the intensity of feeding on the control species. In choice tests the value of this index depends on the presence, in the tested set, of species whose attractiveness to slugs is comparable to that of the control species (B. napus). Consumption is the mean intensity of slug feeding on plants of the species concerned per unit time and reflects the rate of feeding. Both palatability and consumption in choice tests can be analysed in the light of the whole set of tested species. Acceptability is determined in relation to the remaining tested species. Each index describes different properties of particular species in the tested set. 


\section{RESULTS}

\section{SLUG IDENTIFICATION}

All the anatomically identified specimens had characteristic features of A. subfuscus, matching WIKTOR's (2004) description. The hermaphroditic gland was small and hidden among the hepatopancreas lobes, the hermaphroditic duct was thin and strongly coiled near the albumen gland. The atrium was oval and symmetrical. The oviduct in its posterior part was thin and gradually widening anteriorly, with two longitudinal ridges inside, the ridges fusing at the outlet. The vas deferens was thin and widening towards the epiphallus. At the outlet to atrium the epiphallus had a ring-like swelling. The spermatheca was rounded and had a thin duct. The oviduct, epiphallus and spermatheca duct opened close to each other in the posterior part of atrium. All the slugs were rusty-coloured, with darker lateral streaks on the mantle and in the post-pallial section of dorsum; they had darker pigment around the pneumostome.

\section{OCCURRENCE OF SLUGS IN OILSEED RAPE PLANTATIONS}

In field observations, in each of the two winter oilseed rape plantations two slug species were present: A. subfuscus and D. reticulatum (Fig. 1). Besides, in the plantation near Kłodzko, in some traps single specimens of A. distinctus Mabille, 1868 and A. silvaticus Lohmander, 1937 were found. In the first plantation (Kłodzko), the number of $A$. subfuscus per trap ranged from 0 to $8(\mathrm{SD}=2.26)$, and the number of $D$. reticulatum from 6 to $31(\mathrm{SD}=6.39)$. In the second plantation (Pisarzowice), the number of $A$. subfuscus was 0-6 per trap $(\mathrm{SD}=1.95)$, and of D. reticulatum 3-19 (SD=3.94). The number of D. reticulatum was 4-5 times greater than that of $A$. subfuscus. The mean degree of damage to the oilseed rape plants was $11.7 \%$ in the first plantation and $4.5 \%$ in the second.

\section{CHOICE TESTS}

In the laboratory, after $24 \mathrm{hrs}$ of feeding of $A$. subfuscus, eight plant species showed slight damage of similar size (Table 1). Significant differences in the degree of damage to various tested plant species appeared after three days of slug feeding. The slugs fed on nearly all plant species except Chelidonium maius L., Euphorbia helioscopia L. and Plantago lanceolata L. The most damaged species was Brassica napus L. var. oleifera. The differences became more pronounced after ten days of slug feeding. The most damaged species were B. napus $(74 \%)$, Tripleurospermum inodorum (L.) Schulz-Bip. (71\%), Melandrium album (Mill.) Garcke (70\%), Thlaspi arvense L. (62\%), Chenopodium album L. $(60 \%)$ and Capsella bursa-pastoris (L.) Med. (59\%). Ch. maius and $P$. lanceolata showed no damage. After 20 days of slug feeding, plants of nine species were damaged in over 88\%; among them $M$. album and $T$. inodorum were damaged in $97.5 \%$. Ch. maius $(34.2 \%)$ and P. lanceolata $(35.8 \%)$ were the least damaged.

After three days of feeding of $A$. subfuscus, B. napus (Table 2) showed the highest acceptability index A. I. = 3.9. It was followed by T. inodorum, Ch. album, M. album and C. bursa-pastoris (A.I.>1.4). Not accepted species (A.I.<0.1) included Ch. maius, E. helioscopia and $P$. lanceolata. B. napus and T. inodorum showed the highest indices of palatability (P.I.) and consumption (C.I.), and were followed by Ch. album and M. album. Plants with the lowest indices were Ch. maius, E. helioscopia and P. lanceolata.

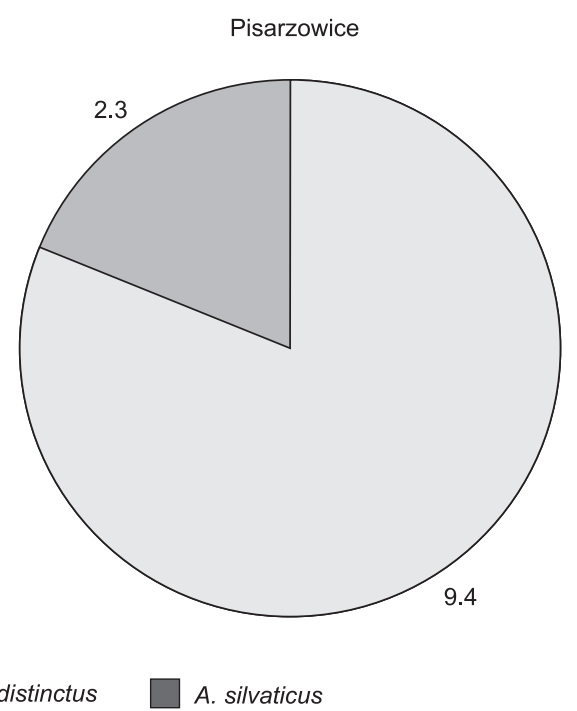

Fig. 1. Mean number of slugs caught in baited traps in the two winter oilseed rape plantations 
Table 1. Rate of damage to oilseed rape seedlings and various herbaceous species (\% area consumed) by Arion subfuscus

\begin{tabular}{|c|c|c|c|c|}
\hline \multirow{2}{*}{ Plant species } & \multicolumn{4}{|c|}{ Day of feeding } \\
\hline & 1 & 3 & 10 & 20 \\
\hline Amaranthus retroflexus $\mathrm{L}$. & $0.00 \mathrm{a}$ & $5.00 \mathrm{~b}$ & $31.67 \mathrm{abc}$ & $72.50 \mathrm{abc}$ \\
\hline Brassica napus L. var. oleifera & $11.67 \mathrm{a}$ & $50.00 \mathrm{a}$ & $74.17 \mathrm{a}$ & $78.33 \mathrm{abc}$ \\
\hline Capsella bursa-pastoris (L.) Med. & $0.00 \mathrm{a}$ & $18.33 \mathrm{ab}$ & $58.33 \mathrm{a}$ & $90.83 \mathrm{a}$ \\
\hline Chelidonium maius $\mathrm{L}$. & $0.00 \mathrm{a}$ & $0.00 \mathrm{~b}$ & $0.00 \mathrm{c}$ & $34.17 \mathrm{c}$ \\
\hline Chenopodium album $\mathrm{L}$. & $3.33 \mathrm{a}$ & $23.33 \mathrm{ab}$ & $59.17 \mathrm{a}$ & $91.67 \mathrm{a}$ \\
\hline Conium maculatum $\mathrm{L}$. & $5.00 \mathrm{a}$ & $6.67 \mathrm{~b}$ & $32.50 \mathrm{abc}$ & $75.00 \mathrm{abc}$ \\
\hline Euphorbia helioscopia L. & $0.00 \mathrm{a}$ & $0.00 \mathrm{~b}$ & $6.67 \mathrm{bc}$ & $40.83 \mathrm{bc}$ \\
\hline Lamium amplexicaule $\mathrm{L}$. & $7.50 \mathrm{a}$ & $14.17 \mathrm{~b}$ & $51.67 \mathrm{ab}$ & $96.67 \mathrm{a}$ \\
\hline Lamium purpureum L. & $0.00 \mathrm{a}$ & $10.83 \mathrm{~b}$ & $36.67 \mathrm{abc}$ & $84.17 \mathrm{ab}$ \\
\hline Melandrium album (Mill.) Garcke & $0.00 \mathrm{a}$ & $22.50 \mathrm{ab}$ & $70.00 \mathrm{a}$ & $97.50 \mathrm{a}$ \\
\hline Myosotis arvensis (L.) Hill. & $0.00 \mathrm{a}$ & $10.00 \mathrm{~b}$ & $26.67 \mathrm{abc}$ & $55.00 \mathrm{abc}$ \\
\hline Plantago lanceolata $\mathrm{L}$. & $0.00 \mathrm{a}$ & $0.00 \mathrm{~b}$ & $0.00 \mathrm{c}$ & $35.83 \mathrm{c}$ \\
\hline Plantago maior $\mathrm{L}$. & $2.50 \mathrm{a}$ & $12.50 \mathrm{~b}$ & $35.00 \mathrm{abc}$ & $55.83 \mathrm{abc}$ \\
\hline Polygonum nodosum Pers. & $0.00 \mathrm{a}$ & $0.83 \mathrm{~b}$ & $27.50 \mathrm{abc}$ & $88.33 \mathrm{a}$ \\
\hline Rumex acetosa $\mathrm{L}$. & $0.83 \mathrm{a}$ & $9.17 \mathrm{~b}$ & $40.83 \mathrm{abc}$ & $59.17 \mathrm{abc}$ \\
\hline Rumex acetosella $\mathrm{L}$. & $0.00 \mathrm{a}$ & $9.17 \mathrm{~b}$ & $35.83 \mathrm{abc}$ & $83.33 \mathrm{ab}$ \\
\hline Sinapis arvensis $\mathrm{L}$. & $2.50 \mathrm{a}$ & $17.50 \mathrm{ab}$ & $53.33 \mathrm{ab}$ & $94.17 \mathrm{a}$ \\
\hline Stellaria media Vill. & $0.00 \mathrm{a}$ & $9.17 \mathrm{~b}$ & $44.17 \mathrm{abc}$ & $94.17 \mathrm{a}$ \\
\hline Thlaspi arvense $\mathrm{L}$. & $6.67 \mathrm{a}$ & $7.50 \mathrm{~b}$ & $61.67 \mathrm{a}$ & $96.67 \mathrm{a}$ \\
\hline Tripleurospermum inodorum (L.) Schultz-Bip. & $0.00 \mathrm{a}$ & $30.00 \mathrm{ab}$ & $70.83 \mathrm{a}$ & $97.50 \mathrm{a}$ \\
\hline
\end{tabular}

Values folloved by different letters within columns are significautly different at $\alpha=0.05$ in Tukey's test

Table 2. Indices of acceptability (A.I.), palatability (P.I.) and consumption (C.I.) for various plant species after 3 days of feeding of Arion subfuscus

\begin{tabular}{|c|c|c|c|}
\hline Plant species & A.I. & P.I. & C.I. \\
\hline Amaranthus retroflexus $\mathrm{L}$. & 0.39 & 0.100 & 1.67 \\
\hline Brassica napus L. var. oleifera & 3.90 & 1.000 & 16.67 \\
\hline Capsella bursa-pastoris (L.) Med. & 1.43 & 0.367 & 6.11 \\
\hline Chelidonium maius L. & 0.00 & 0.000 & 0.00 \\
\hline Chenopodium album $\mathrm{L}$. & 1.82 & 0.467 & 7.78 \\
\hline Conium maculatum $\mathrm{L}$. & 0.52 & 0.133 & 2.22 \\
\hline Euphorbia helioscopia L. & 0.00 & 0.000 & 0.00 \\
\hline Lamium amplexicaule $\mathrm{L}$. & 1.10 & 0.283 & 4.72 \\
\hline Lamium purpureum $\mathrm{L}$. & 0.84 & 0.217 & 3.61 \\
\hline Melandrium album (Mill.) Garcke & 1.75 & 0.450 & 7.50 \\
\hline Myosotis arvensis (L.) Hill. & 0.78 & 0.200 & 3.33 \\
\hline Plantago lanceolata $\mathrm{L}$. & 0.00 & 0.000 & 0.00 \\
\hline Plantago maior $\mathrm{L}$. & 0.97 & 0.250 & 4.17 \\
\hline Polygonum nodosum Pers. & 0.06 & 0.017 & 0.28 \\
\hline Rumex acetosa $\mathrm{L}$. & 0.71 & 0.183 & 3.06 \\
\hline Rumex acetosella $\mathrm{L}$. & 0.71 & 0.183 & 3.06 \\
\hline Sinapis arvensis $\mathrm{L}$. & 1.36 & 0.350 & 5.83 \\
\hline Stellaria media Vill. & 0.71 & 0.183 & 3.06 \\
\hline Thlaspi arvense $\mathrm{L}$. & 0.58 & 0.150 & 2.50 \\
\hline Tripleurospermum inodorum (L.) Schultz-Bip. & 2.34 & 0.600 & 10.00 \\
\hline
\end{tabular}




\section{DISCUSSION}

Till recently $A$. subfucus was believed to occur mainly in forest habitats and to feed on fungi and herbaceous plants (FRÖMMING 1954, CHICHESTER \& GETZ, 1969, 1973, RIEDEL \& WIKTOR 1974, WIKTOR 2004). Some data suggest however that it can be found also in plantations where it sometimes causes serious damage (GLEN et al. 1992, HOMMAY 2002, GLEN \& MOENS 2002, KOZŁOWSKI 2003). Numerous signals from pest control authorities and plant growers suggest that the slug increasingly often occurs in gardens and some agricultural crops, for example oilseed rape.

Slug identification in this study showed that the collected individuals represented one of the forms of A. subfuscus, recorded by WIKTOR $(1973,2004)$ from Poland. The form has dark lateral streaks on the mantle and postpallial dorsum section. Another form found in Poland is olive-coloured or greyish, with no lateral streaks, and reaches a big size (up to $7 \mathrm{~cm}$ ). The third form which is very rare in Poland has chocolate-brown back and creamy sides, with no lateral streaks (RIEDEL \& WIKTOR 1974, WIKTOR 2004). The systematic status of these slugs has not been fully explained. GARRIDO et al. (1995) showed that in the northern part of the Iberian Peninsula A. subfuscus was a complex of five forms. Based on the structure of genitalia, spermatophores and mating behaviour, besides A. subfuscus (Draparnaud, 1805), they separated new species: A. iratii, A. lizarrustii, A. molinae and A. cf. gilvus. Genetic studies on the material from Scandinavia, northern part of the Netherlands and northern Germany (PINCEEL et al. 2004) revealed the presence of two taxa within A. subfusus s.l.: A. subfuscus (Draparnaud, 1805) and A. fuscus (O. F. Müller, 1774), both occurring in north-western Europe. The name Arion subfuscus is still commonly used to refer to the complex of species in various parts of Europe and was adopted in this paper.

Arion subfuscus occurs in winter oilseed rape plantations, but its abundance is $4-5$ times lower than that of $D$. reticulatum. An even greater difference in the abundance of the two slugs was observed by GLEN et al. (1989): in fields prepared for wheat sowing they found six times as many $D$. reticulatum as A. distinctus and $A$. subfuscus, at a similar biomass of the three species. They found also that the biomass was more important than abundance when estimating the danger to cereal crops. This is understandable in view of the great variation in the size and weight among the species, for example $A$. subfuscus and D. reticulatum. The proportion of $A$. subfuscus was found to be low when many slug species were present in the same site (SIONEK \& KOZŁOWSKI 1999). However, other observations suggest that though $A$. subfuscus rarely occurs in masses, in some gardens its density may exceed ten individuals per $1 \mathrm{~m}^{2}$ (own, unpublished data).
Literature information on plant damage by $A$. subfuscus is scanty. It is known to damage agricultural crops: vegetables, cereals, oilseed rape, maize, soya and sunflower. Most damage is done just after germination (GLEN et al. 1992, HAMMOND \& BYERS 2002, HOMMAY 2002, GLEN \& MOENS 2002). In gardens the slug can damage many vegetable species, some ornamental plants and strawberries (KOZŁOWSKI 2008). Winter oilseed rape damage observed in the two plantations was probably an effect of combined feeding of A. subfuscus and D. reticulatum. It is difficult to estimate the proportion of damage attributable to A. subfuscus.

In the laboratory among the 20 tested plant species, B. napus was preferred by A. subfuscus; T. inodorum, Ch. album, M. album and C. bursa-pastoris were also readily eaten. A similarly high attractiveness of $B$. napus was demonstrated for D. reticulatum, A. lusitanicus and A. rufus (GLEN et al. 1993, BARRATT et al. 1994, BRINER \& FRANK 1998, FRANK 1998, FRANK \& FRIEDLI 1999, KOZŁOWSKI \& KAŁUSKI 2004, KOZŁOWSKI \& KOZŁOWSKA 2003, 2004). Besides B. napus, the three slug species preferred Conium maculatum and Lamium amplexicaule (KOZŁOWSKI \& KOZŁOWSKA 2003). BRINER \& FRANK (1998), in their experiments on palatability of 78 species of herbaceous plants to $A$. lusitanicus, showed that besides B. napus preferred plants included C. bursa-pastoris, Lamium purpureum L. and Sinapis arvensis L. FRANK \& FRIEDLI (1999) observed that both $A$. lusitanicus and D. reticulatum preferred B. napus and C. bursa-pastoris. C. bursa-pastoris was also mentioned as much preferred by Deroceras caruanae (Pollonera, 1891) (DIRZO 1980).

Plants not accepted by A. subfuscus included $C h$. maius, E. helioscopia and P. lanceolata. In earlier studies P. lanceolata was not accepted by D. reticulatum, A. lusitanicus and A. rufus (KOZŁOWSKI \& KOZŁOWSKA 2003). Similar results, on poor acceptance of the species, were obtained by DIRZO (1980) for D. caruanae, by BRINER \& FRANK (1998) for A. lusitanicus and by MOLGAARD (1986) for Helix pomatia.

The results of this study and the literature data show that palatability and acceptability to slugs varies among plant species. The main reason is the varied chemical composition which affects slug feeding behaviour (WEBBE \& LAMBERT 1983, MOLGAARD 1986, PORT \& PORT 1986, SPAULL \& ELDON 1990, CLARK et al. 1997). Furthermore, because of feeding specialisations of various slug species, only some plants, for example B. napus, are similarly acceptable to all slugs; the same pertains to some unacceptable plants, e.g. P. lanceolata.

The data on palatability and acceptability of the tested species to A. subfuscus provide new information on food preferences of the slug. The acceptable and unacceptable species may be potentially used in pro- 
tection of rape seedlings from A. subfuscus. Future studies should include molecular analysis of the forms of $A$. subfuscus from various locations in Poland, in order to explain their taxonomic status. More informa-

\section{CONCLUSIONS}

1. Arion subfuscus occurs in winter oilseed rape plantations, but its density is several times smaller than that of D. reticulatum.

2. Like other herbivorous gastropods, A. subfuscus shows different preferences to different plant species.

\section{REFERENCES}

BARRATt B. I. P., BYERS R. A., BIERLEIN D. L. 1994. Conservation of tillage crop yields in relation to grey garden slug (Deroceras reticulatum) (Müller)) (Mollusca: Agriolimacidae) density during establishment. Crop Protection 13: 49-52.

BRINER T., FRANK T. 1998. The palatability of 78 wildflower strip plants to the slug Arion lusitanicus. Ann. Appl. Biol. 133: 123-133.

Chichester L. F., GeTZ L. L. 1969. The zoogeography and ecology of arionid and limacid slugs introduced into northeastern North America. Malacologia 7: 313-346.

CHICHESTER L. F., GETZ L. L. 1973. The terrestrial slugs of northeastern North America. Sterkiana 51: 11-42.

Clark S. J., Dodds C. J., Henderson I. F., Martin A. P. 1997. A bioassay for screening materials influencing feeding in the field slug Deroceras reticulatum (Müller) (Mollusca: Pulmonata). Ann. Appl. Biol. 130: 379-385.

DIRZO R. 1980. Experimental studies on slug-plant interactions. I. The acceptability of thirty plant species to the slug Agriolimax caruanae. J. Ecol. 68: 981-998.

FRANK T. 1998. Slug damage and numbers of the slug pests, Arion lusitanicus and Deroceras reticulatum, in oilseed rape grown beside sown wildflower strips. Agr. Ecosys. Environ. 67: 67-78.

FRANK T., FRIEDLI J. 1999. Laboratory food choice trials to explore the potential of common weeds to reduce slug feeding on oilseed rape. Biol. Agr. Hort. 17: 19-29.

FRÖMmING E. 1954. Biologie der mitteleuropäischen Landgastropoden. Berlin-München.

Garrido C., Castillejo J., Iglesias J. 1995. The Arion subfuscus complex in the eastern part of the Iberian Peninsula, with redescription of Arion subfuscus (Draparnaud, 1805). Arch. Moll. 124: 103-118.

GLEN D. M. 1989. Understanding and predicting slug problems in cereals. In: Slugs and snails in world agriculture (HENDERSON I. F., ed.). Monograph 41, pp. 253-262, British Crop Protection Council, Thornton Heath.

Glen D. M., Milsom N. F., Wiltshire C. W. 1989. Effects of seed-bed conditions on slug numbers and damage to winter wheat in a clay soil. Ann. Appl. Biol. 115: 117-190. tion on the occurrence of and damage caused by $A$. subfuscus in plantations is also necessary to estimate its significance as pest.

3. Plant species accepted and not accepted by $A$. subfuscus may be used in alternative methods of its control in plantations.

GLEN D. M., WiltshiRe C. W., Milsom N. F. 1992. Some aspects of forecasting slug damage in arable crops. J. Med. Appl. Malacol. 4: 147-152.

GLEN D. M., MoENS R. 2002. Agriolimacidae, Arionidae and Milacidae as pests in west European cereals. In: Molluscs as crop pests (BARKER G. M., ed.), pp. 271-300, Oxford University Press, Oxford.

Glen D. M., Spaull A. M., Mowat D. J., Green D. B., JaCKSON A. W. 1993. Crop monitoring to assess the risk of slug damage to winter wheat in the United Kingdom. Ann. Appl. Biol. 122: 161-172.

HAMmond R. B., BYers R. 2002. Agriolimacidae and Arionidae as pests in conservation-tillage soybean and maize cropping in North America. In: Molluscs as crop pests (BARKER G. M., ed.), pp. 301-314, Oxford University Press, Oxford.

Hommay G. 2002. Agriolimacidae, Arionidae and Milacidae as pests in west European sunflower and maize. In: Molluscs as crop pests (BARKER G. M., ed.), pp. 245-254, Oxford University Press, Oxford.

KOZŁOWSKA M., KOZŁOWSKI J. 2002. Miary oceny preferencji pokarmowej ślimaków wobec różnych gatunków roślin. Colloq. Biometr. 32: 287-297.

KOZŁOWSKA M., KozŁOWSKI J. 2004. Consumption growth as a measure of comparisons of results from no-choice test and test with multiple choice. J. Plant Protection Res. 44: 251-258.

KOZŁOWSKI J. 2003. Stan badań nad metodami zwalczania szkodliwych ślimaków. Post. Nauk Rol. 5: 25-42.

KOZŁOWSKI J. 2008. Obcy inwazyjny ślimak nagi ślinik luzytański - Arion lusitanicus. Charakterystyka, metody zwalczania i rejestracji stanowisk występowania w Polsce. Rozpr. Nauk. Inst. Ochr. Roślin 17: 1-48.

KozŁowski J., KaŁuski T. 2004. Preferences of Deroceras reticulatum (O.F. Müller), Arion lusitanicus Mabille and Arion rufus (Linnaeus) for various weed and herb species and winter oilseed rape. (II group plants). Folia Malacol. 12: 173-180.

KOZŁOWSKI J., KOZŁOWSKA M. 2003. Evaluation of food preferences and tolerance of slugs Deroceras reticulatum, Arion lusitanicus and Arion rufus (I group of plants) with prefer- 
ences to various herbs. J. Plant Protection Res. 43: 381-392.

KOZŁOWSKI J., KOZŁOWSKA M. 2004. Food preferences of Deroceras reticulatum, Arion lusitanicus and Arion rufus for various medicinal herbs and oilseed rape. J. Plant Protection Res. 44: 239-250.

MESCH H. 1996. Was hilft gegen Schnecken im Raps? Top. Agrar. 8: 52-53.

MoEnS R., GLEN D. M. 2002. Agriolimacidae, Arionidae and Milacidae as pests in west European oilseed rape. In: Molluscs as crop pests (BARKER G. M., ed.), pp. 425-439, Oxford University Press, Oxford.

MOLGAARD P. 1986. Food plant preferences by slugs and snails: a simple method to evaluate the relative palatability of the food plants. Bioch. Syst. Ecol. 14: 113-121.

PinceEl J., JORDAENS K., VAN HOUTTE N., DE WinTER A. J., BACKELJAU T. 2004. Molecular and morphological data reveal cryptic taxonomic diversity in the terrestrial slug complex Arion subfuscus/fuscus (Mollusca, Pulmonata, Arionidae) in continental north-west Europe. Biol. J. Linn. Soc. 83: 23-38.

PORT G., ESTER A. 2002. Gastropods as pests in vegetable and ornamental crops in western Europe. In: Molluscs as crop pests (BARKER G. M., ed.), pp. 337-351, Oxford University Press, Oxford.
PORT C. M., PORT G. R. 1986. The biology and behaviour of slugs in relation to crop damage and control. Agr. Zool. Rev. 1: 255-299.

RIEDEL A. 1988. Ślimaki lądowe. Gastropoda terrestria. Katalog Fauny Polski 36. PWN, Warszawa.

RIEDEL A., WIKTOR A. 1974. Arionacea- ślimaki krążałkowate i ślinikowate (Gastropoda: Stylommatophora). Fauna Polski 2. PWN, Warszawa.

SIONEK R., KOZŁOWSKI J. 1999. Species composition and abundance dynamics of slugs (Gastropoda Terrestria Nuda) in urban conditions. Folia Malacol. 7: 115-122.

SPAull A. M., ELDON S. 1990. Is it possible to limit slug damage using choice of winter wheat cultivars? Proceedings of the Brighton Crop Protection Conference - Pests and Diseases - 1990, vol. 2: 703-708.

WebBe G., LAmberT J. D. H. 1983. Plants that kill snails and prospects for disease control. Nature 302: 754.

WIKTOR A. 1973. Die Nacktschneken Polens (Arionidae, Milacidae, Limacidae) (Gastropoda, Stylommatophora). Monografie Fauny Polski 1. PWN, Warszawa.

WikTOR A. 2004. Ślimaki Lądowe Polski. Mantis, Olsztyn.

Received: October 10th, 2008

Accepted: November 5th, 2008 